\author{
G.G. Baikenova ${ }^{1}$, T.V. Benz ${ }^{1}$, L.M. Sugralina ${ }^{2}$ \\ ${ }^{1}$ Karaganda Economic University of Kazpotrebsouyz, Kazakhstan; \\ ${ }^{2}$ Ye.A. Buketov Karaganda State University, Kazakhstan \\ (E-mail:murzabek_b@mail.ru)
}

\title{
Analysis of the quality of water resources of the Republic of Kazakhstan
}

\begin{abstract}
The article summarizes and analyzes the data of observations on the condition of water resources of the Republic of Kazakhstan. The rivers and lakes of Kazakhstan are sources of water consumed by the population of the country for various needs, while the availability of water is reduced, and the demand for it is growing due to the development of large cities and expansion of business in various regions of the country. Therefore the problem of saving and rational usage of available water resources is topical. The article shows the factors affecting the quality of water in open reservoirs as well as the results of observations of fresh water sources for five years. The analysis of data presented testifies to the deterioration of the environmental situation as a whole. The number of water resources having class of hazard «pure» is decreasing, and the number of water sources of «dirty» and «very dirty» classes is increasing. It is noted that the most contaminated areas are the territories of East Kazakhstan and Karaganda, Aktobe and Zhambyl regions. The level of pollution of fifteen water resources was determined, it was noted that the main pollutants are zinc, manganese, nickel and nitrogen compounds. The analysis of the data presented indicates the need to address the serious problem caused by fresh water pollution due to an increase in the amount of sewage, and ways to solve this problem should have a legislative basis that will protect the environment from the harmful effects of anthropogenic factors.
\end{abstract}

Keywords: water resources of the Republic of Kazakhstan, rivers, pollution, pollutants, environmental protection.

Water occupies a special place among the natural resources of our planet. It is known that less than $30 \%$ of the Earth's surface is land, and everything else is the World Ocean. And although there is a lot of water on the globe, it is not evenly distributed across the countries and regions of the Earth. It should be borne in mind that fresh water is negligible, it means about $3 \%$ together with the ice of the Arctic, Greenland and Antarctica in relation to the general water resources of our planet.

Resources of surface river waters of the Republic of Kazakhstan according to the State Committee of the Republic of Kazakhstan on average are estimated at 100.9 billion $\mathrm{m}^{3}$ per year of which $56.5 \%$ are formed in Kazakhstan and $44.4 \%$ amount comes from adjacent territories such as China, Republic of Uzbekistan, Republic of Kyrgyzstan and the Russian Federation [1, 2].

Our country occupies the last rating among the former Soviet Union republics for water availability. Specific water availability is about 36,000 per $1 \mathrm{~km}^{2}$ and $6,000 \mathrm{~m}^{3}$ per person per year [2].

There are eight river basins on the Kazakhstan territory, the largest of which are Irtysh, BalkhashAlakol, Aral-Syrdarya and Zhayik-Caspian, it consists more than $90 \%$ of water resources in total.

In general Kazakhstan water resources are unevenly distributed across regions. Thus $34.5 \%$ of all water resources are in the Eastern region, $4.2 \%$ in the North, $2.6 \%$ in the Central region, $24.1 \%$ in the South, $21.2 \%$ in the Western South, $13.4 \%$ in the West.

Total resources of fresh water are estimated at $524 \mathrm{~km}^{3}$ including $80 \mathrm{~km}^{3}$ of water locating on the glaciers, $190 \mathrm{~km}^{3}$ of water are concentrated in lakes, the resources of the rivers contain $101 \mathrm{~km}^{3}$. Reserves of groundwater make up $7.6 \mathrm{~km}^{3}$, including next points: for domestic and drinking water supply $-5.6 \mathrm{~km}^{3}$; for household, drinking and industrial and technical water supply $-0.4 \mathrm{~km}^{3}$; for domestic and drinking water supply together with irrigation of land $-1.3 \mathrm{~km}^{3}$ [3].

At present $67 \%$ of the population of Kazakhstan can use the central system of drinking water supply, while in Russia this figure is $89 \%$, in Great Britain, Germany, France, Singapore and Israel it is almost $100 \%$. Access to the centralized system of water disposal is less than half of the country's population, in Germany and France - $93 \%$, the UK - $98 \%$. By 2040 it is expected to increase the irretrievable consumption of water for public utilities up to $1.4 \mathrm{~km}^{3}$ (an average of $1.9 \%$ per year). The population growth is projected to 20.8 million people, which will lead to an increase in water consumption up to $35 \%$, while the urban population will increase from the current $53 \%$ to $73 \%$ due to the formation of agglomeration centers on the basis of the largest cities of Kazakhstan such as Astana, Almaty and Shymkent with a population of at least two million people as well as Aktobe and Aktau which have a high proportion of the able-bodied population and where small and medium businesses are most actively developing. As the country develops other 
major cities of Kazakhstan may become centers of agglomeration, which will require the construction of a new water infrastructure to meet the needs of the growing population of agglomerations in water supply and sanitation [3].

The situation with lack of affordable drinking water, waste water and waste water treatment is aggravated by the backlog in the technical support and repair of the existing infrastructure of centralized water supply. A significant part of the communal infrastructure is in a dilapidated state, which leads to high water losses. On a nationwide scale they account for about $40 \%$ of the total amount which is significantly higher than in countries such as the USA (11\%), Russia (21\%), the UK (23\%). One of the reasons for the backlog in infrastructure development is the weak tariff setting mechanism, which does not allow covering operational and investment costs [4].

The general unsatisfactory state of assets (over $60 \%$ worn ones) worsens the quality of the services of centralized water supply. The efficiency of public services in Kazakhstan lags behind those of the United Kingdom, Italy, and Russia: there are 1.5 to 4 employees per thousand water users, while it is 0.3 to 1.3 person in other countries [5].

In general the gradual economic recovery of the demand for water will increase as the population becomes larger. In this connection it is necessary to carry out large-scale works on saving and rational use of water resources [5].

Parameters of drinking water quality standards in Kazakhstan generally correspond to European standards and the World Health Organization, but the levels of the maximum allowable values of international standards, for example, for turbidity, are often more stringent.

According to the Committee for Consumer Protection of the Ministry of National Economy of the Republic of Kazakhstan, the main reasons affecting the quality of water in open reservoirs are:

- non-observance of the size of water protection zones,

- the formation of spontaneous household dumps,

- effluent of industrial and agricultural objects,

- accommodation of residential and industrial facilities on the banks of river beds without coordination with the sanitary epidemiological service, accidents on sewer networks, and others [3].

The level of surface water pollution was estimated from the complex index of water pollution (IWM), which is used to compare and identify the dynamics of water quality changes and varies insignificantly from year to year (Table 1).

T a b l e 1

Distribution of water bodies with a class of hazard

\begin{tabular}{|l|c|c|c|c|c|}
\hline \multirow{2}{*}{ Class of hazard } & \multicolumn{5}{c|}{ Amount of water bodies } \\
\cline { 2 - 6 } & 2011 & 2012 & 2013 & 2014 & 2015 \\
\hline «Pure» & $13(15.3 \%)$ & $23(21.5 \%)$ & $25(22.9 \%)$ & $18(16.2 \%)$ & $10(9.9)$ \\
\hline$\ll$ Moderately polluted» & $52(61.2 \%)$ & $49(45.8 \%)$ & $52(47.7 \%)$ & $49(44,1 \%)$ & $65(60.8)$ \\
\hline$\ll$ Polluted» & $12(14.1 \%)$ & $26(24.3 \%)$ & $17(15.6 \%)$ & $28(25.2 \%)$ & - \\
\hline$\ll$ Dirty» & $5(5.9 \%)$ & $6(5.6 \%)$ & $6(5.5 \%)$ & $11(9.9 \%)$ & - \\
\hline$\ll$ Uery dirty» & $1(1.2 \%)$ & $2(1.9 \%)$ & $9(8.3 \%)$ & $3(2.7 \%)$ & $33(28.3)$ \\
\hline «Extremely dirty» & $2(2.35 \%)$ & $1(0.9 \%)$ & - & $2(1.8 \%)$ & $1(1.0)$ \\
\hline
\end{tabular}

In 2014-2015 the number of water bodies of the class «pure» has decreased compared with 2012-2013.

In 2015 the number of water bodies with the class «very dirty»(33) increased compared with 2011$2013(2011-1,2013-2,2013-9)$.

The observations on the quality of surface waters by hydro chemical indicators were carried out at 215 hydro chemical stations, which were distributed in 88 water bodies in 2011; then 240 hydro chemical sections were distributed for 104 water bodies in 2012. In 2013-2015 observations were made on 240 hydro chemical stations, which were distributed on 109 water bodies, namely 71 rivers, 16 lakes, 14 reservoirs, 3 canals, 1 sea [3].

Constant water pollution occurs in water bodies on the territory of the East Kazakhstan area, Karaganda, Aktobe, Zhambyl regions by heavy metals, nutrients and organic substances, in connection with the historical discharges of chemicals (the river Ilekbor, pollutant is chrome), a historical accident at a chemical plant (Lake. Biilikol - increase in BOD5), obtaining of purification discharges from mining and mining enterprises (the rivers Cherubaynura, Kara-Kengir, Sokyr, Nura, pollutants are nitrogen nitrite, ammonium salt, 
copper, zinc, oil products, phenol S), (the rivers Krasnoyarka, Breksa, Tikhaya, Glubochanka, pollutants are zinc, cadmium, copper, iron, manganese, ammonium salt) (Table 2).

In addition, excess MPCs are fixed due to high background concentrations of chemicals in the regions. For example, in the basin of the river Tobyl there were manganese, nickel, iron; in the mountain rivers of the Ile river basin copper, fluorides were; In Balkash - Alakol systems of lakes and lakes of Shchuchinsk Borovoe resort zone there was high mineralization.

Table 2

Information on pollution of surface waters of the Republic of Kazakhstan

\begin{tabular}{|l|c|l|}
\hline \multicolumn{1}{|c|}{ Name of water body, region } & Level of pollution & \multicolumn{1}{c|}{ Name of pollutants } \\
\hline Elek river (Aktobe region) & «Very dirty» & Boron, chromium (6+), ammonium saline \\
\hline Esil river (Akmola region) & «Very dirty» & Nitrogen, manganese \\
\hline $\begin{array}{l}\text { Glubochanka river } \\
\text { (East Kazakhstan) }\end{array}$ & «Very dirty» & Zinc, manganese \\
\hline Brex river (East Kazakhstan) & «Very dirty» & Zinc, manganese \\
\hline Tikhaya river (East Kazakhstan) & «Very dirty» & Zinc, manganese \\
\hline $\begin{array}{l}\text { Krasnoyarka river } \\
\text { (East Kazakhstan) }\end{array}$ & «Very dirty» & Zinc, manganese \\
\hline Ulba river (East Kazakhstan) & «Very dirty» & Zinc, manganese \\
\hline Tobyl river (Kostanay region) & «Very dirty» & Manganese, nickel \\
\hline Nura river (Karaganda region) & «Very dirty» & Manganese, nitrite nitrogen \\
\hline $\begin{array}{l}\text { Kara Kengir river } \\
(\text { Karaganda region) }\end{array}$ & «Extremely dirty» & Ammonium saline, manganese, nitrite nitrogen \\
\hline $\begin{array}{l}\text { Kokpekty river } \\
(\text { Karaganda region) }\end{array}$ & «Very dirty» & Manganese \\
\hline $\begin{array}{l}\text { Samarkand Reservoir } \\
(\text { Karaganda region) }\end{array}$ & «Very dirty» & Manganese \\
\hline $\begin{array}{l}\text { Sokyr river (Karaganda region) } \\
\text { (Karaganda Region) }\end{array}$ & «Extremely dirty» \\
\hline $\begin{array}{l}\text { Nura-Yesil Channel } \\
\text { Karaganda region) }\end{array}$ & Manganese, nitrite nitrogen, ammonium salt \\
\hline
\end{tabular}

Pollution and scarcity of water resources constitute a serious environmental problem for the sustainable development of Kazakhstan. Currently rational use of water resources is an extremely urgent problem. This, above all, protecting water areas from pollution, and since industrial wastewater is the first in terms of the volume and damage that they cause, it is first of all necessary to solve the problem of dumping them into rivers. In particular, it is necessary to limit discharges into reservoirs, as well as improvement of production, purification and utilization technologies. Also it is important to collect charges for the discharging sewage and pollutants and to transfer levied funds for the development of new non-waste technologies and treatment facilities.

Apparently, the ways to solve the problem of water resources pollution in Kazakhstan lie primarily in the development of a developed legislative framework that would allow to really protect the environment from harmful anthropogenic impact, as well as to find ways to implement these laws in practice.

\section{References}

1 Берденов Ж.Г. Источники загрязнения водных ресурсов как одна из главных проблем рационального природопользования в Казахстане / Ж.Г. Берденов, Е.Х. Мендыбаев, Г.М. Джаналеева // Науки о Земле: вчера, сегодня, завтра: материалы Междунар. науч. конф. (Казань, 20-23 мая 2015 г.). - Казань: Бук, 2015. - С. 78-84.

2 Нечаева В.Л. Водные ресурсы как фактор сохранения национальной безопасности Республики Казахстан: дис. ... канд. полит. наук / В.Л. Нечаева. - Астана, 2006. - С. 65-70.

3 [ЭР]. Режим доступа: http://ecodoklad.kz 
4 Гусева Л.Ю. // Аналитический обзор. - 2010. - № 1. - С. 56-58.

5 Байкенова Г.Г., Тусупова К.М. // Вестн. КЭУ. — 2012. — № 4. — С. 122-124.

\title{
Г.Г. Байкенова, Т.В. Бенц, Л.М. Сугралина
}

\section{Қазақстан Республикасының жерүсті суларының сапасын сараптау}

\begin{abstract}
Мақалада Қазақстан Республикасының су қорларының жағдайын бақылау мәліметтері сарапталды және қорытылды. Қазақстанның өзендері мен көлдері ел халқымен әртүрлі қажеттеліктерге қолданылатын су көзі, сондықтан жарамды сулар қоры азаюда, ал оған деген қажеттілік елдің әртүрлі аймақтарында бизнестің кеңеюімен және ірі қалалардың дамумен артуда. Сондықтан бар су қорларын сақтау және тиімді қолдану өзекті болып табылады. Мақалада ашық резервуарлардағы су сапасына әсер ететін факторлар және соңғы бес жылда тұщы су қорларын бақылау нәтижелері келтірілген. Мәліметтерді сараптау жалпы экологиялық жағдайдың нашарлағанын көрсетті. «Таза» санаттағы су қорларының саны азайып, ал «лас» және «өте лас» санаттағы су қорларының мөлшері артуда. Шығыс Қазақстан аудандары және Қарағанды, Ақтөбе және Жамбыл облыстары ең ластанған аймақтар болып табылды. Он бес су қорларының ластану дәрежесі анықталды, негізгі ластандырғыштар болып мырыш, марганец, никель және азот қосылыстары екені табылды. Көрсетілген мәліметтер ағынды сулардың артуымен тұщы судың ластануына негізделген күрделі мәселелерді шешу қажеттігінің дәлелі және бұл мәселені шешу қоршаған ортаны антропогенді фактордың зиянды әсерінен қорғауға мүмкіндік беретін заңдық тұрғыда болуы қажет.
\end{abstract}

Кілт сөздер: Қазақстан Республикасының су қорлары, өзендер, ластану, ластаушы заттар, қоршаған ортаны қорғау.

\section{Г.Г. Байкенова, Т.В. Бенц, Л.М. Сугралина}

\section{Анализ качества поверхностных вод Республики Казахстан}

\begin{abstract}
В статье обобщены и проанализированы данные наблюдений о состоянии водных ресурсов Республики Казахстан. Реки и озера Казахстана являются источниками воды, потребляемой населением страны для различных нужд, при этом запасы пригодной воды уменьшаются, а потребность в ней растет в связи с развитием крупных городов и расширением бизнеса в различных регионах страны. Поэтому проблема сохранения и рационального использования имеющихся водных ресурсов является актуальной. В статье указаны факторы, влияющие на качество воды в открытых резервуарах, а также результаты наблюдений за источниками пресной воды за пять лет. Анализ представленных данных свидетельствует об ухудшении экологической обстановки в целом. Число водных ресурсов класса «чистый» уменьшается, а количество источников воды класса «грязный» и «очень грязный» увеличивается. Отмечено, что наиболее загрязненными регионами являются территории Восточного Казахстана, Карагандинской, Актюбинской и Жамбылской областей. Был определен уровень загрязнения пятнадцати водных источников. Отмечено, что основными загрязнителями являются цинк, марганец, никель и соединения азота. Анализ представленных данных свидетельствует о необходимости решения серьезной проблемы, обусловленной загрязнением пресной воды из-за увеличения количества сточных вод, причем пути решения этой проблемы должны иметь законодательную основу, что позволит защитить окружающую среду от вредного влияния антропогенного фактора.
\end{abstract}

Ключевые слова: водные ресурсы Республики Казахстан, реки, загрязнения, загрязняющие вещества, защита окружающей среды.

\section{References}

1 Berdenov, Zh.G., Mendybaev, E.Kh., \& Dzhanaleeva, G.M. (2015). Istochniki zahriazneniya vodnykh resursov kak odna iz hlavnykh problem ratsionalnoho prirodopolzovaniia $v$ Kazakhstane [Sources of water resources pollution as one of the main problems of rational nature management in Kazakhstan]. Proceedings from Earth Sciences: Yesterday, Today, Tomorrow' 15: Mezhdunarodnaia nauchnaia konferentsiia (20-23 maia) — International Scientific Conference (pp. 78-84). Kazan: Buk [in Russian].

2 Nechaeva, V.L. (2006). Vodnye resursy kak faktor sokhraneniia natsionalnoi bezopasnosti Respubliki Kazakhstan [Water Resources as the Factor of Maintenance of National Safety of Republic Kazakhstan]. Candidate's thesis. Astana [in Russian].

3 (n.d.). Retrieved from http://ecodoklad.kz [in Russian]

4 Guseva, L.Yu. (2010). Analiticheskii obzor - Analytical Review, 1, 56-58 [in Russian].

5 Baikenova, G.G., \& Tusupova, K.M. (2012). Vestnik KEU - Bulletin of KEU, 4, 122-124 [in Russian]. 